\title{
The concept of paratextuality in literary genre Chick-lit
}

\author{
Pojęcie paratekstualności w gatunku literackim Chick-lit
}

\author{
Aleksandra SIKORA ${ }^{1}$ \\ Ateneum-Szkoła Wyższa w Gdańsku
}

Summary

This text is an analysis of the concept of paratext based on contemporary literature. In addition to the theoretical part concentrating on the idea of Gérard Genette, some information on the Chick-Lit genre appeared in the article. Among other things, genre characteristics, historical backgrounds and biographical notes of the authors of the analysed novels were described. Genette's theory clearly shows that an inseparable part of the book as a final product is its cover and what the reader finds on it. These are, among others, the title, abstract, of significance is also the colouring or even the location of the author's name. All these elements have been described in detail and analysed according to what Gérard Genette's gives.

Keywords: paratext, chick-lit, women, Gérard Genette, paratextuality, coherence, stereotype, book cover, novel

\section{Streszczenie}

Niniejszy tekst stanowi analizę pojęcia paratekstualności opartą na literaturze współczesnej. Obok części teoretycznej, dotyczącej konceptu Gérarda Genette'a, w artykule przedstawione zostały informacje na temat omawianego gatunku Chick-lit. Opisane zostały między innymi cechy gatunkowe, tło historyczne oraz notki biograficzne o autorkach analizowanych powieści. Z teorii Génette'a wynika, iż nieodłączną częścią książki, jako produktu końcowego, jest jej okładka oraz to, co czytelnik na niej znajduje. Są to między innymi tytuł, streszczenie, nie bez znaczenia jest również kolorystyka, czy chociażby umiejscowienie nazwiska autora. Wszystkie te

1 (C) https://orcid.org/0000-0002-5242-4978

Ateneum-Szkoła Wyższa w Gdańsku, Wydział Neofilologiczny

a.sikora@ateneum.edu.pl 
elementy zostały szczegółowo opisane i poddane analizie zgodnie z założeniami koncepcji Gérarda Genette'a.

Słowa kluczowe: paratekst, chick-lit, kobiety, Gerard Genette, paratekstualność, spójność, stereotyp, okładka książki, powieść

\section{Introduction}

Bridget Jones, Andrea Sachs, Louisa Clark, Holly, Allie or Rosie, all mentioned earlier, are very famous, both in their times and ages later. The listed women are not recognisable for any prizes; they are a group of typical women from the neighbourhood. Starting from the first book of Chick-lit, many subsequent novels become bestsellers on a global scale and create an excellent base for the scripts for cinema hits or musicals, with their authors receiving numerous awards.

As for a reasonably young genre, present in the publishing world less than twenty-five years, it has won readers' hearts. An unquestionable means of achieving success on such a scale was identifying the target group precisely; Helen Fielding has not built a perfect literary world with even more perfect heroes. She dared the idea that her heroine was not an ideal blonde in size thirty-four, whose only dream is to catch a rich husband.

This article is a short analysis of the content and its coherence to the cover of the particular novel. Nowadays, the recipient of the book firstly checks the outside of the product, later, if it interests him, decides to take a look at the inside. The same story is in the literary world. According to the concept of paratextuality by Gérard Genette, I will try to present the strong connection between the cover and the content of the two books from the literary genre, Chick-lit.

\section{A general overview of a new woman's fiction, Chick-lit}

Stories written by women, about women, for women to read; this is the shortest and the basic definition of a Chick-lit published by Cambridge Dictionary. The above description contains one main component of the mentioned literary genre: a woman, an author, the Independent's created Bridget and published in character, and a reader. Comparing Chick-lit to the Novel of Manners is a widespread phenomenon. It is not shocking because the author of famous Bridget Jones's Diary, which is recognised as the first book of the new literary genre of Chick lit, admits that Jane Austen's 
plots inspired her, and a few of them are used in the story about Bridget; however, the main difference is the time of these two bestsellers. Bridget's life spans the end of the 20th century, whereas the world of Elizabeth is presented two centuries earlier, in the late 18th century.

The term Chick list was used by novelist Cris Mazza and her co-editor Jeffrey DeShell in Chick-Lit: Postfeminist Fiction (1995) and Chick-Lit: No Chick Vics (1996) for the very first time. She explained that it was for ironic reasons, and surprisingly the term became an official brand name. In Mazza's subsequent work Who's Laughing Now?: A Short History of Chick-Lit and the Perversion of a Genre, she analyses how the term Chick lit works and compares and explains differences between this name used by the publishing industry and by herself as a mock word.

Following the first use of the name, Chick-lit many definitions appeared very quickly, not only in the famous article Chick lit 101 but also in popular magazines. According to literary critics, Chick lit may be treated as a form of women's fiction based on the subject matter, character, audience, and narrative style. Simply, the chick-lit protagonist is a woman in her twenties or thirties who navigates her generation's challenges of life and work balance, which is the satisfaction of her career and personal relationship (Cabot). Unfortunately, it failed to avoid associations with Chick lit to the modern romance stories popularised by Harlequin in the United States and Millis and Boon in the United Kingdom. In the essay Tradition and Displacement in the New Novel of Manners, Stephanie Harzewski support Chick lit and explained that this new genre presents a more realistic picture of a single woman's life. Relating to chicklit.us reviews, this modern woman's fiction reflects the everyday life of working young women and men; what is more, reach out to readers "who want to see their own lives in all the messy detail, reflected in fiction today". The protagonist of chick lit is typically slightly flawed than perfect, who evokes empathy from the reader and easy identification with the main character. Another popular feature is an incredible sense of humour and easiness of laughing at herself and the current situation in her life, which is not as positive as she wants to be. Thanks to this, readers consider that they are imperfect, too. It is not the end of the world. To follow chicklit.us, "the heroine of these books can be rude, shallow, overly compulsive, neurotic, insecure, bold, ambitious, witty or surprisingly all of the above - but we love them anyway!". Relating to some literary critics' opinions, this genre generally rejects investment in fashion and cocktails and forces the reader to reflect on consumer culture. Jennifer Weiner, an 
American writer, explains why Chick lit has become the so-called commercial tsunami: I think that for a long time what women were getting were sort of the Jackie Collins, Judith Krantz kind of books - sex and shopping, glitz and glamour, heroines that were fun to read about, but just felt nothing like where you were in your life.

It is not surprising that many new woman's fiction authors based their stories on their own experiences; for example, as already mentioned by Jennifer Weiner in her first novel, Good in Bed, she used clues of a painful breakup she had experienced. Also, Plum Sykes or Lauren Weisberger used their experiences from private lives as an inspiration for the plot and characters in their books. Thanks to this literary device, readers are impression that the book they read is not fiction and very often identify the protagonist lives with the writer. Responsible for this identification is the narrative style that is applied in chick lit books. Opposite to traditional chivalric novels, chick-lit authors use first-person narration and adapt everyday language with a keen sense of humour and sharp jokes. This way of presenting the protagonist's struggles with her work, relationships, feelings, and sharing her secrets make an impression of a casual daily conversation between the book's main character and the reader.

As mentioned above, chick-lit is not an entirely original literary genre. It is somewhat a refreshed continuation of 18th-century romantic stories or utilisation of a well-known literary pattern. However, it is also compared and linked to Harlequin stories or the traditional superficial romance. In the first official critique of the romances formula, Germaine Greer wrote that it is possible to define it as "trash and mush". The completely ineffective protagonist tries to build her career path from the beginning and unsuccessfully strike a balance in her love life. Greer also claimed that the heroine is trapped in her chains, her beliefs of the romantic love myth or a prince on a white horse who will protect her from the whole world. Some critics, such as Grescoe, repute that Chick-lit akin to Harlequin always ends with inconceivable happiness of two main characters, which might build the impression that both literary genres, typical romance and Harlequin, are the same.

Notwithstanding, one only needs to look at such authors as Lisa Cach, Melissa Sante or today's Jojo Moyes to ascertain that a happy ending is not always linked with being together for the rest of life. Chick-lit rejects a traditional vision of relationships and the role of women in society; the protagonist's union with Mr Right is not only a requisite, but it also evolves through different steps. Similarly, equal attention is given to the protagonist's 
self-definition, striking a balance between social and work life; the genre responds to the upheavals in dating and, what is more, places the heroine in the new postfeminist reality. Previous fights for women's rights, such as equal pay for equal work, changed into the dilemma of choosing because there are too many opportunities, as Carrie Bradshaw illustrates in the famous Sex and the City novel. Opposite to the traditional love story, chick-lit stands upon the protagonist and two men trying to solicit her attention, and she is the only one who decides which one is Mr Right.

\section{Famous Chick-lit authors}

Helen Fielding is an English author and screenwriter, recognised mostly by her trilogy about Bridget Jones, for which she won The British Book of The Year award. She graduated from Wakefield Girls High School, and after that, she studied English at St Anne's College, Oxford. Fielding's career path began in 1979 on the $\mathrm{BBC}$; when she worked as a regional researcher for the news magazine Nationwide, she upgraded to be a production manager of children and light entertainment shows. 1989 gave Helen a job as a researcher for the series When Hunger is a Weapon for Thames TV, about the rebel war in Southern Sudan, which builds the base for her first novel, satire Cause Celeb, 1994. In 1990-1999, she worked for a few national newspapers, The Sunday Times, The Telegraph and The Independent, as a journalist and columnist. The Independent's last title turned out an important one and enabled her to become a writer and gain popularity in the literary industry as Bridget Jones's Diary. Helen Fielding gets the offer from the publisher to write a column about her life in London as a single working woman. However, she rejects this offer because she would not publicly show her private life; she created Bridget and published anonymously. With time, the column gained popularity, and Helen Fielding agreed to write a book about Bridget. The book became a worldwide bestseller and came with two more parts, Bridget Jones: The Edge of Reason and Bridget Jones: Mad About The Boy, and three screenings of Bridget's story, with Rene Zellweger and Colin Firth as the main characters. Together with popularity, Helen faced speculation about her private life and comparison to famous Pride and Prejudice because of a similar stylistic formula: intertextuality. Many reviews and even fans of Bridget and Helen claim that she based Bridget Jones: Mad About The Boy on her own experience of being a widow and a single mother of two children. In 2009 she published a short-story collection called $O x$-tales. 
The second famous Chick-lit writer is Lauren Weisberger, an American novelist well known for her first book, The Devil Wears Prada. She graduated from Parkland High School in 1995, where she was involved in different activities, for example, intramural sports, competitive sports, special projects and several organisations. In 1999 she graduated from Cornell University in Ithaca, New York when her major was English. After studies, Lauren travelled through Europe, Israel, Egypt, Jordan, Thailand, India, Nepal and Hong Kong. After returning to America, she moved to Manhattan and started to work as an assistant of Anna Wintour, editor-in-chief of Vogue. Weisberger worked for American Vogue for ten months; then, she left Vogue with feature editor Richard Story. The next stop for Weisberger and Story was Departures Magazine; after writing a 100-word review, she became an assistant editor; in 2004, she published an article in Playboy magazine. When Lauren demonstrated her interest in writing, Richard Story recommended her to his friend Charles Salzberg, an American novelist, journalist and teacher. Weisberger started describing her time in Vogue, writing 15 pages every couple of weeks and completed her first book; after that, she showed her first novel to agents and sold it within two weeks. The Devil Wears Prada was published in 2003 and was on the New York Times Best Seller List, and three years later, a movie based on the novel of the same title turned out to be one of the topgrossing films of summer 2006. Both the book and the movie received many good reviews, for fiction as well written Chick lit genre and video for the screenplay and excellent cast; in one scene, spectators may see Lauren as a nanny of Miranda's twins. Other literary positions written by Weisberger is Everyone Worth Knowing (2005), Chasing Harry Winston (2008), Last Night at Chateau Marmont (2010), a sequel of The Devil..., Revenge Wears Prada (2013), The Singles Game (2016) and the second sequel of The Devil When Life Gives You Lululemons (2018).

\section{Welcome to Bridget}

The novel is a diary of a thirty-year-old single woman, a Londoner who works for a publishing house; she has a degree in English from the University of Bangor. Bridget Jones, the protagonist, starts a new year with a hangover, single and with many new year's resolutions: for example, finding true love and losing weight. Every day she sumps up smoking several cigarettes, drinking alcohol and a batch of eaten calories. From time to time, Bridget also summarises her dates, jobs or even phone calls and messages on voicemail. The author, who Bridget portrays, describes chronically not only events in her 
life but also her feelings and struggles; the reader accompanies Bridget in happiness and sadness throughout the whole year. The first meeting with Bridget is at traditional Una and Geoffrey Alconbury's New Year's Day turkey curry buffet. Firstly, Mark's and Bridget's parents suggest getting closer to each other; however, their first impression was completely different and brought an opposite reaction.

As a consequence of her unpleasant experiences, the protagonist decides to change her entire life and fight for her dreams. Bridget, after many interviews, gets a job in Good Morning Britain, a morning TV lifestyle program. Her premiere live broadcast unfortunately fails, and she must prove herself to maintain her position, and ultimately, Mark comes to the rescue. The attorney gives Bridget an exclusive interview about a controversial case that he leads. Thanks to it, the reporter is seen in a new perspective, both by her colleagues and the boss. Beyond doubt, another consequence of this situation is the transition between Bridget and Mark; they change the way they think about each other and consider their acquaintanceship in categories of a future relationship. When relations between those two are getting warmer, Daniel Cleaver returns to Bridget's life. Jones is confused about the feelings that she has for Mark and her attitude to Daniel. For the second time, because of Cleaver, Bridget decides to look for romantic love and focus on her friendship and relationship with her parents. In the meantime, Mark chooses to have a last-chance talk with Bridget, and she ends the year with one new job, one boyfriend and still drinking alcohol and smoking, but enormously happy.

\section{The protagonist of Chick-lit in the 21st Century}

Another book in the Chick-lit genre is The Devil Wears Prada by Lauren Weisberger, published at the beginning of the 21st century. The reader meets the main character at a somewhat strategic moment in her life, so as a recent graduate of the University of Brown in Providence, she must decide her adult life. Andrea, the heroine, decides to move to New York because, as she claims, this is the only place where she can fulfil her dream of being a journalist at The New Yorker. After arriving in the city, she submits her CV in all possible areas, believing that she will be a step closer to her dream job if she catches an engagement in any title. Surprisingly, she gets a response from Runway, a fashion magazine, offering the position of editor-in-chief assistant. Sachs is an intellectual who ignores external appearance and adheres to the principle that the look does not constitute grounds for judging someone 
but a closer acquaintance. The first day at work already becomes a challenge for Andrea as she tries to be true to her beliefs, but the longer she works at Runway, the more convinced she becomes that at this company, first and foremost, the principle that they see is what they write you.

Furthermore, Nigel, the creative director at the magazine, comes to help and shows Andy that the world of fashion and beauty can be fascinating. The right look changes not only the attitude of others but also the person's wellbeing as he perceives himself. Andrea notices the change straightaway after the image change; colleagues from the office begin to catch her, and the boss almost tolerates her. The world in which Andrea finds herself begins to impress her; well-known names, big parties, tinsel, glamour, and all that at the expense of her relationships with her boyfriend and friends.

The conflict between Andrea and Alex increases, they pass each other; Andrea is more and more absorbed in Runway and Miranda's matters, while Alex is abandoned with his work at school and homegrown problems. Andrea feels more and more misunderstood and lonely, making her even more devoted to working for Miranda and Runway. At one of the parties, she meets a handsome young writer, Christian Collinsworth. It turns out that Andrea regularly reads his reports, which impress her incredibly. Christian is fascinated by the Priestly'sung, attractive assistant and, to get into her favours, he proposes introducing her to several influential people from the press world. The girl is stunned by the handsome writer, who offered help in starting a journalistic career. Getting to know Christian makes Andrea believe even more complex that the hard and full of sacrifice work at Runway so far has made sense because she just took her first step on the road to her dreams. However, one day Sachs discovers that Christian is involved in a case related to Miranda's dismissal from Runway, which forever damages their further acquaintance, at least on her part. Andy tries to discuss the situation with the boss at all costs, but it turns out that she already knows everything and has made efforts to keep Runway's top post. Afterwards, Andy feels as if she has woken up from a dream; she realises she did not want such a life. Sachs decides to quit instantly; she believes it is not too late to rebuild her old life.

\section{Explanation of the paratext theory by Gérard Genette}

The final version of the book, which is the product people see on the shelves in bookstores, is the final result of the work of many people with many individual elements put together. In the literary world, each of these components has its name and appears at a certain point during the book's 
creation process. The content, i.e. the threads described in the novel, is the proper text. In contrast, all other components, such as titles, subtitles, subheadings, preface, afterword, introductions, notes from the publisher, margin notes, epigraphs, illustrations, advertising inserts, notes on the dust jacket or band and all additional signals, the pen of the author or other people, forming a (variable) wrapper, as well as texts that are a commentary to it (reviews, discussions, notes in publishing catalogues, folders, etc.) are referred to as paratext. Gerard Genette proposed this term to describe all of the above elements around the aforementioned proper text. Often, the paratext makes the text a book and, as a book, goes to the reader or, more generally, to the audience.

Paratextuality appeared for the first time in Genette's work from 1979 Introduction a l'architexte to describe the relationships between one text and earlier texts, with the author referring to imitations and transformations, i.e. intertextual derivations such as pastiche or parody, as a result of which paratext was to appear. A few years later, Genette defined the above phenomena as hypertextual relations (Genette, 1982) while reserving paratextuality for transtextual references between the actual text and the accompanying elements. Finally, Genette devoted a separate publication to paratexts in which he described their features and functions (Genette, 1987).

Paratext consists of various groups of practices and discourses whose common interests or convergence of effects are more important than the fundamental variety of their aspects. According to Genette, paratext is borderline (Genette, 1987). The nature of the concept is reflected by the prefix para-, which contains its antithesis while denoting closeness and distance, similarity and difference. It allows placing the paratext on both sides of the boundary line, representing the internal and external space of the text. The text thus constitutes the transaction space between the reader and nontext: a free space for the pragmatic dimensions of the work. In this way, Genette draws attention to the illocutionary power of paratext. A paratextual statement can inform about something, reveal intentions, and interpret the text. The author may promise something in it and commit to something; they may defend themself and their work against something, allow it, advise, order and even threaten. From the perspective of paratext's illocutionary force, its functional aspect grows, which Genette considers key, while paratextuality is also defined as a category in its universal way. According to Genette, text without paratext does not exist (and never existed) because any way of giving the reader a form of communication (even oral or graphic) gives paratextual 
effects (presents the work to the audience). Paratext cannot, however, exist without the text to which it refers and which is its purpose (even if the text was not materially available and appeared only in the form of a title or reference; examples may include references to ancient, unsaved texts or the use of literary trick of writing about a non-existent book).

Genette defines several statuses of paratextual elements that allow formulating the main criteria for their classification. For example, the spatial quality allows to distinguish categories of paratexts by their location; temporal status - due to the moment the paratext was issued; substantive status - due to the way information is provided in the para-text. In turn, the pragmatic quality of a paratext is defined by the features of the communication situation in which it has appeared: the nature of the sender and addressee, the level of sender's authority and their responsibility for this paratext.

As the basis of the typology of paratexts, Genette adopted the sender's criterion (author and editor) and the criterion of their spatial location (including the text or independently). In addition to his fundamental division, more functional classifications also appeared. An interesting typology of paratexts in the works of superiors was formulated by Urpo Kovala (Kovala, 1996). He divided the paratexts in translations into the following categories: modest paratexts - containing only the necessary elements; commercial paratexts - related to advertising other items of a given publishing house; informative paratexts - describing the work and placing them in a specific context, illustrative paratexts - illustrations on the first and last page of the cover. Unfortunately, Kovala's categorisation does not fit easily into Genette's systematic division of paratexts.

Paratext theory formulated by Gérard Genette found its continuation in many literary scholars who have enriched the subject matter by further contexts. The seminar's first followers were his seminarians, including Yasusuke Oura, Jean-Marie Schaeffer, Randa Sabry and Wolfgang Leiner, whose compact work can be found in the monothematic volume Poetique of 1987 (No. 69). Marie Maclean wrote from the perspective of speech acts that the author of the paratext informs, persuades, advises, admonishes the reader, even disposes of them (Maclean, 1991). The function of paratexts and the author-text relationship (instead of the author-reader relationship) was also considered, which, according to researchers, determines paratexts (Chambers, 1988). Leiner, mentioned above, wrote about the functions of preface in literary works and the relation of the paratext to the recipient (Leiner, 1990). On the other hand, Lane's work developed the paratext issue 
in a direction quite narrowly treated in Genette's work and related to the editorial paratext (Lane, 1994).

\section{The book cover and its cohesion in Chick-lit literary genre}

An inseparable element of the book, apart from its content, is, among other things, the cover and what appears on it, i.e. the title of the novel, its summary, author's description, publishing note, sometimes reviews of that book. Because in addition to the content itself, the cover also draws the customer's attention, its design has become an integral part of every book.

A feminine cover does not necessarily mean pink, full of flowers, hearts and other romantic attributes; for a woman of the late twentieth century, who enters the world of post-feminism, begins to fight for her place in the labour market and defy stereotypes, the cover should display strength, courage, but also soothing calmness and unobtrusive romanticism.

The first element of the cover that has been analysed is the title. In both novels, it occupies a significant part of the site and appropriately as the first attracts attention, although they are visually very different. In Bridget, the title is stored with a simple, ordinary font in navy blue. Large letters were used only to write the name and the name of the title heroine, while the word Diary was saved to a small letter. The recipient seeing such a record has a feeling that this is a diary of the so-called girl from the neighbourhood, not a novel. In the case of The Devil, the title already has lively colours, orange and red, the font is bold, and the whole is saved with small letters; also, the name of the famous Prada fashion brand starts with a small letter.

Another thing in the cover, which is nevertheless essential than the title, is the name of the author of the book. In the case of the first name, Helen Fielding stands out with red colour; the font itself is consistent with this used to write the title. In the second novel, Lauren Weisberger's name is stored in a very soft grey colour, although the capital letters were used to record. You should also pay attention to the placement of Authors' names; Fielding appears under Bridget Jones's, but before the diary's expression, which creates a kind of game with the recipient. The reader may be tempted to ask if this diary is Bridget or Helen? In turn, Weisberger is placed at the very bottom of the cover, thus creating a basis for the cover, which can also be referring to the fact that Lauren writing The Devil was based on her life.

Bridget Jones's Diary depicts a strong woman with a cigarette in her hand, who gives the impression of readiness for anything happening now 
and what a new era will bring. She is a woman who does not look back and calmly looks at what is just in front of her, is elegant, well-groomed and with bold jewellery. In turn, the colours of the cover are bright, delicate, and they are instead a background for the female character so that she is brought to the foreground; looking at the body only, the reader knows that in this book she will find strength, courage, but also peace and fulfilment that is so important in women's lives.

The second book's cover, The Devil Wears Prada, created in the 21st century, is adapted to its time. However, the surface still maintains the standard of the genre, i.e. the body is not exaggerated, instead of emanating feminine strength and calmness, rather than infancy in the form of light powder colours often assigned to women and icons. The Devil Wears Prada cover also features a female character, but another aspect of it; in Bridget Jones's Diary, it was the face and shoulders, but here we can see almost the whole silhouette, from feet to half of the neck. The figure depicted on the cover can be easily called iconic because it reflects a thoroughly modern woman of the 21st century, well-dressed, bravely wearing expensive jewellery and fashionable, costly accessories. She is a decisive woman, which can be deduced from the arrangement of hands, one placed on the hip, the other raised with the index finger extended; this author winks at the readers with this cover by adding a devil's tail which completes the whole message. The recipient of the book sees that she will find in it a heroine who is brave, strong, and confident in her value, who is not afraid of challenges and is certainly not an angel, as it may seem at first glance. She bravely walks through life, reaching for her professional dreams and those related to family and love life. The Devil Wears Prada cover is all white but has one strong red accent, representing strength against a white background, gentleness, and peace.

\section{Conclusion}

The cover of the book is often the first thing the reader meets. It is visible on the shelves in bookstores, on websites, or in ads promoting the novel. In recent years, consumers, due to the development of the sphere of marketing and promotion, have started to pay more attention to the content proposed by the author and everything that creates the book in its entirety. There is a cover, a summary of the novel, a note from the author, and several reviews encouraging to reach for this book. In these demanding times, coherence between the cover and the book's content, the body is essential so that 
the reader, seeing the outside, is intrigued by what is inside and wants to read it. The covers of both novels analysed in this article suit their content, message, and audience; all the elements form a coherent whole - a final product, which is a book available in a bookstore or a digital form.

\section{REFERENCES}

Batchelor, K. (2018). Translation and Paratexts. Routledge.

Brzostowska-Tereszkiewicz, T. (2011). Parateksty w przekładzie literaturoznawczym. Między oryginałem a przekładem, 17, 217-229.

De los Reyes, A. (2013). DIY Chick Lit: A Writing Guide. KMR Publishing.

Ehriander, H. (2015). Chick Lit in Historical Settings by Frida Skybäck. Journal Of Popular Romance Studies, 5.1, 1-12. Retrieved on March 6, 2021 from http://jprstudies.org/tag/ chick-lit/

Fielding, H. (2012). Bridget Jones's Diary. Pan MacMillan.

Ferris, S., \& Young, M. (2006). Chick-lit: the new woman's fiction. Routledge

Fest, K. (2009). Angels in the House or Girl Power: Working Women in Nineteenth-Century Novels and Contemporary Chick Lit. Women's Studies, 38(1), 43-62.

Gelder, K. (2004). Popular Fiction: The Logics and Practices of a Literary Field. Routledge.

Genette, G. (1979). Introduction a l'architexte. Le Seuil.

Genette, G. (1980). Narrative Discourse. Cornell University Press.

Genette, G. (1982). Palimpsestes. La literature au second degré. Le Seuil.

Genette, G. (1987). Thresholds of interpretation. Cambridge University Press.

Harzewski, S. (2011). Chick Lit and Postfeminism. Charlottesville and London: University of Virginia Press.

Holmes, L.-A. (2014, January 22). Chick lit? Hate the term. Love the genre. The Guardian. https:/www.theguardian.com/commentisfree/2014/jan/22/chick-lit-hate-term-lovegenre-fiction-fourth-wave-feminism

Kovala, U. (1995). Translation, Paratextual Mediation and Ideological Closure. Target (vol. 8). John Benjamins Publishing Company.

Loewe, I. (2007). Gatunki paratekstowe w komunikacji medialnej. Wydawnictwo Uniwersytetu Śląskiego.

Loewe, I. (2004). Parateksty, pre-teksty czy możliwe para-gatunki? Gatunki mowy i ich ewolucje. Tekst a gatunek. Wydawnictwo Uniwersytetu Śląskiego.

Mazza, C., \& DeShell, J. (1995). Chick-Lit: Postfeminist Fiction. Fiction Collective 2.

Mazza, C., \& DeShell, J. (1996). Chick-Lit: No Chick Vics. Fiction Collective 2.

Montoro, R. (2013). Chick lit: The Stylistics Of Cappuccino Fiction. Bloomsbury.

Mlynowski, S., \& Jacobs, F. (2015). See Jane Write: A Girl's Guide To Writing Chick Lit. Quirk Books.

Mullan, J. (2013, November 27). Because we know Bridget's story comes from Jane Austen, we also know roughly where it must go. The Guardian. https://www.theguardian.com/ books/2013/nov/27/bridget-jones-s-diary-helen-fielding-book-club

Rosenfeld, L. (2017, February 3). What Was Chick lit? A Brief History From The Inside. Literary Hub. https://lithub.com/what-was-chick-lit-a-brief-history-from-the-inside/

Stanitzek, G. (2005). Texts and Paratexts in Media. The University of Chicago Press. 
Thomas, S. (2002, August 4). The great Chick lit conspiracy. The Independent. https:/www.independent.co.uk/arts-entertainment/books/features/the-great-chick-litconspiracy-172223.html

Thorpe, V. (2001, April 8). The Observer Profile: Helen Fielding Private diarist. Sunday Observer

Weisberger, L. (2004). The Devil Wears Prada. Broadway Books. 